Article

\title{
Vegetation Degradation and Its Driving Factors in the Farming-Pastoral Ecotone over the Countries along Belt and Road Initiative
}

\author{
Qionghuan Liu ${ }^{1,2}$, Xiuhong Wang ${ }^{1}$, Yili Zhang ${ }^{1,2,3, *}$, Huamin Zhang ${ }^{4}$ and Lanhui Li ${ }^{1,2}$ \\ 1 Key Laboratory of Land Surface Pattern and Simulation, Institute of Geographic Sciences and Natural \\ Resources Research (IGSNRR), CAS, Beijing 100101, China; liuqh.16b@igsnrr.ac.cn (Q.L.); \\ wangxh@igsnrr.ac.cn (X.W.); lilh.15b@igsnrr.ac.cn (L.L.) \\ 2 University of Chinese Academy of Sciences, Beijing 100049, China \\ 3 CAS Center for Excellence in Tibetan Plateau Earth Sciences, Beijing 100101, China \\ 4 School of Geography and Environment, Jiangxi Normal University, Nanchang 330027, China; \\ zhanghuamin1995@163.com \\ * Correspondence: zhangyl@igsnrr.ac.cn
}

Received: 27 January 2019; Accepted: 8 March 2019; Published: 15 March 2019

\begin{abstract}
To adhere to the green growth strategy, it is urgently needed to identify the vegetation degradation zone in the farming-pastoral ecotone (FPE) over the countries along the "Belt and Road Initiative (BRI)". In this study, we monitored vegetation degradation and analyzed climatic factors and anthropogenic contributions on vegetation change in the FPE during 2000-2016 using the growing season annual accumulative normalized difference vegetation index (NDVIaccu) and climatic variables. The Theil-Sen's trend results revealed that $74.11 \%$ of NDVIaccu in FPEs showed a significant increasing trend for the period 2000-2016, only 1.64\% of NDVIaccu were significantly decreasing. However, we detected that $21.29 \%$ degradation of NDVIaccu had occurred based on enhanced Theil-Sen and Mann-Kendall (ETheil-Sen-MK) method. Spatial statistics for significant correlations between climatic variables and NDVIaccu showed that precipitation was positively correlated with NDVIaccu; yet, the relationship between NDVIaccu and temperature was more complex, which was closely related to the intensity of increasing in temperature. Importantly, this study found that anthropogenic contributions dominated the trends in NDVIaccu over the FPE. The findings suggested that agricultural activities play a mainly positive role in overall vegetation vigor. However, continually increasing disturbance by livestock grazing risks further vegetation degradation.
\end{abstract}

Keywords: vegetation degradation; remote sensing monitoring; farming-pastoral ecotone; Belt and Road Initiative (BRI)

\section{Introduction}

While there was no internationally accepted definition of vegetation degradation, it can generally be defined as "the decline process of potential vegetation production in landscape variability under natural or artificial disturbances" [1]. Compared to intact plants, degraded vegetation was often lower in biomass, less ecologically productive, fragmented, and lower in canopy cover [2,3]. It has been of great importance to the scientific community to monitor vegetation degradation. Many studies have attempted to use various methods to monitor vegetation degradation. For instance, measurement of changes in species diversity, which had certain advantages in indicating changes in vegetation, but such measurements were based mainly on repeated surveys in the field, focusing on small-scale and long-term vegetation changes [4]. However, difficulties still existed in monitoring large-scale 
species diversity indicators using remote-sensing technologies. In addition, changes in land cover were used to characterize the process of vegetation degradation [5,6]. If natural vegetation was changed to either artificial vegetation or non-vegetation, it was considered as vegetation degradation, the degree of which was difficult to define, however. The most direct manifestation of vegetation degradation was the decline in vegetation parameters such as normalized difference vegetation index (NDVI), net primary productivity (NPP), fractional vegetation coverage (FVC) or leaf area index (LAI) [7-9]. Satellite monitoring had advantages in observing and assessing large-scale and mesoscale vegetation degradation, compared with traditional field-based studies. As a surrogate for measurement of vegetation coverage or productivity, NDVI was one of the most widely used vegetation indices (VIs) in examining vegetation activity at regional and global scales $[10,11]$.

Generally, if there were significantly increasing or decreasing trends for the pixel in VIs, we can determine exactly whether this part of coverage area was either a vegetation restoration area or a vegetation degradation zone [9,12-14]. Previous studies tended to use the parametric (modified least squares, MLS) regression method [15], which was unbiased but required additional information related to either measurement errors or intercept. Therefore, the non-parametric (Theil-Sen) linear regression method $[16,17]$ was widely used, because it easily satisfied the model requirement that measurements were performed by the same instrument and the data follow an underlying model that was close to linear. The trends analysis combined with significance test methods, for instance, Mann-Kendall (MK) test was commonly used to assess vegetation greenness characteristic. But such an integrated approach can only determine areas where significant changes of vegetation have occurred [18-20]. As a consequence, for areas where changes in the VIs were nonsignificant but with high coefficient of variation, the state of the vegetation remains unknown, which was source of error in judging the characteristics of vegetation variation and estimating the extent of degradation. There are few research studies that explore the state of vegetation in regions of no significant changes. Sun (2017) defined a processing procedure which eliminated the effect of precipitation of arid area and took the region of nonsignificant change of vegetation into consideration to detect the land degradation in Inner Mongolia region in China, and the result showed that $3.50 \%$ of land was degenerated, which found more $1.14 \%$ of degradation land than Theil-Sen and Mann-Kendall (Theil-Sen-MK) method $(2.36 \%, p<0.1)$ [5].

FPE is a critically fragile ecosystem in the 'Belt and Road Initiative (BRI)' economic corridor, also known as the Silk Road Economic Belt in which 129 countries are involved across East Asia, South Asia, West Asia, Central Asia and parts of Europe and North Africa (http:/ /eng.yidaiyilu.gov.cn/). FPE vegetation possessed crucial demands on energy budgets, water cycles, and biogeochemical cycles in ecosystems through vegetation activities (e.g., photosynthesis, respiration, and transpiration) [11], and therefore affected Earth's climate systems [21,22]. Due to the arid climate, the vegetation activities in FPE were affected seriously by precipitation, and the degree and extent of vegetation degradation was often underestimated [23]. Therefore, to find out the region of vegetation degradation more reasonably, this paper attempted to combine multiple indicators and synthesized the Theil-Sen, MK test and Pearson correlation analysis methods to grub the region of vegetation degradation.

FPE vegetation suffered from the impacts of both climate change and human activities. Frequent droughts and overgrazing resulted in significant negative changes to the vegetation in FPEs. Since 2016, to protect fragile ecosystems, the concept of the "Green Silk Road" had been advocated, and more studies have focused on the ecosystem environment problems of these areas [24]. However, there are few studies quantifying anthropogenic contributions to vegetation degradation in FPE region. The impact of anthropogenic disturbance on the vegetation activities of FPEs was still unclear. Excitingly, long-term remote sensing data, climatic variables, and the residual analysis method provide the utilities to separate anthropogenic contributions from actual vegetation changes.

Thus, the main objectives of this study were (1) to monitor and identify more subtly the trends of vegetation degradation in FPE over BRI from 2000 to 2016, (2) to investigate the impacts of climate factors and anthropogenic contributions on vegetation changes, and to explain their potential causes and mechanism. 


\section{Study Area}

The FPE located in the semi-arid and dry sub-humid zone, between $0^{\circ}-60^{\circ} \mathrm{N}, 10^{\circ} \mathrm{W}-85^{\circ} \mathrm{E}$, with area of $\sim 2.6 \times 10^{6} \mathrm{~km}^{2}$ (Figure 1), is regarded as typical fragile ecological area in BRI region in view of its sensitivity to climate change and human activities. The FPE spans multiple climate regimes, including a tropical monsoon climate zone, a tropical desert climate zone, a temperate continental climate zone, and a plateau climate zone. According to Shi, the FPE was defined as one with aridity between 0.20 and 0.50 (semi-arid), 0.51 and 0.65 (dry sub-humid), and the average annual precipitation ranging from 300 to $450 \mathrm{~mm}[25,26]$. The average elevation of the FPE is $\sim 1000 \mathrm{~m}$, but there is a huge variation in altitude, with the elevation increasing from 0 to $7050 \mathrm{~m}$, and $50 \%$ of the area has an elevation below $450 \mathrm{~m}$. Cropland and grassland were the major land use types, accounting for $22.13 \%$ and $53.44 \%$, respectively, of the entire study area according to the land use data of 2015 [27].

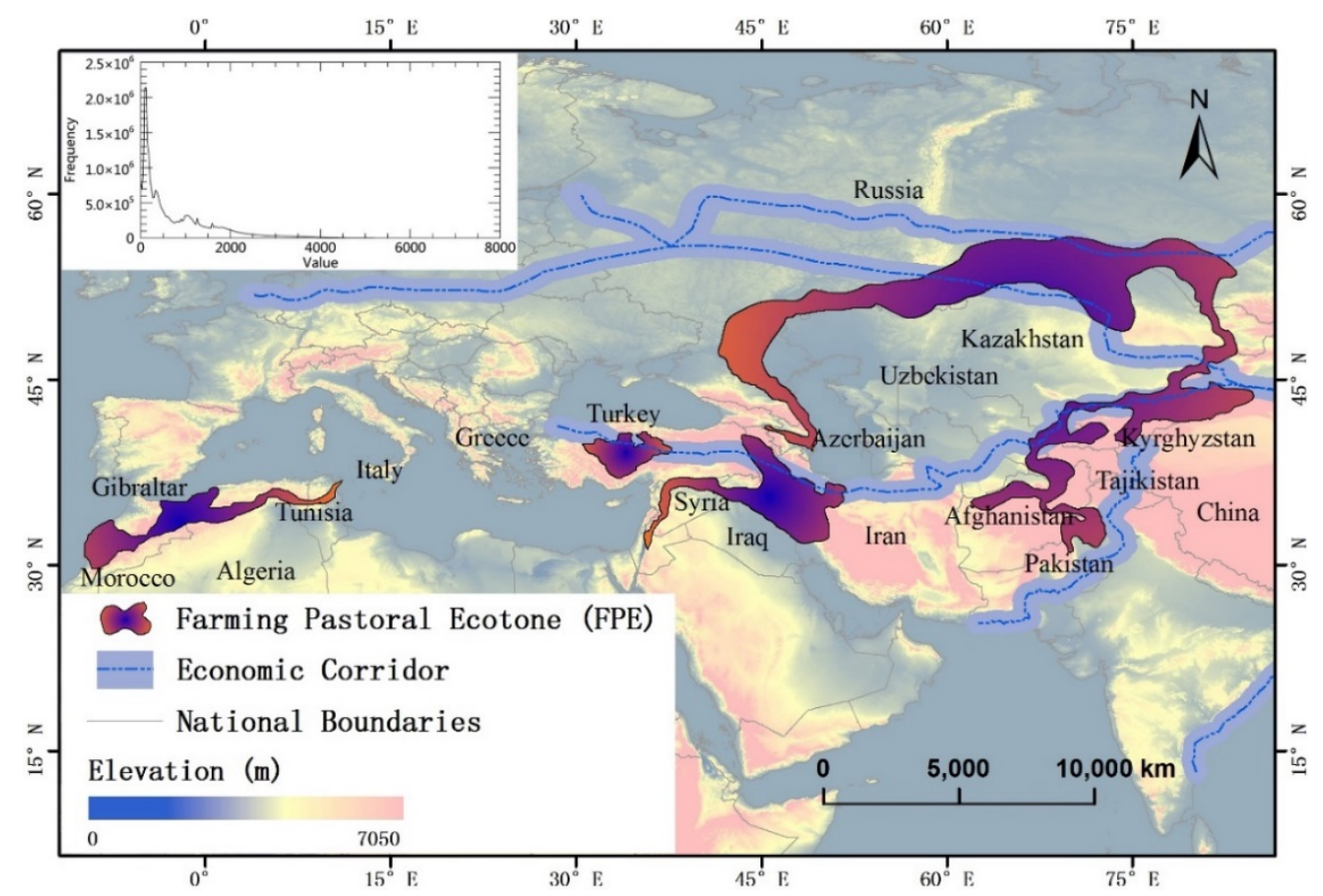

Figure 1. The location of FPE.

\section{Data and Methods}

\subsection{Data}

Data used in this study include NDVI, temperature, precipitation, and potential evapotranspiration and land cover data. The monthly MOD13A3 NDVI data were downloaded from NASA (https:/ /ladsweb.modaps.eosdis.nasa.gov) [28] and span the period from 2000 through 2016 on a $1 \mathrm{~km}$ grid. All images downloaded were mosaicked and re-projected to Albers using the MODIS Reprojection Tools (MRT). Noise induced by poor atmospheric conditions and cloud contamination was inevitable in remote-sensing data. So, we adopted the more robust model of modified Savitzky-Golay (mSG) filter which was verified by most research result to reconstruct a high-quality NDVI $[29,30]$. Furthermore, in order to lessen the deviations in results due to outlier values of certain month in growing season, we used the NDVIaccu to replaced common NDVI by using maximum value composite (MVC) of the fortnightly data set. Monthly gridded data with $0.5^{\circ}$ spatial resolution, including precipitation $(\mathrm{P})$, temperature $(\mathrm{T})$, and potential evapotranspiration $(\mathrm{PE})$ for the period 2000 to 2016, were obtained from CRU TS 3.23 data (http://www.cru.uea.ac.uk/data) [31]. The meteorological data set was based on observations from 4000 meteorological stations around the world and was interpolated using spatial autocorrelation functions $[32,33]$. The land use data were 
downloaded from ESA (http:/ / maps.elie.ucl.ac.be/CCI/) [27] for the period 1992 to 2015 at $300 \mathrm{~m}$ spatial resolution. The land cover data was reclassified into 9 classes, e.g., forest, shrub, grassland, cropland, wetland, rivers and lakes, artificial land, glacier and snow and barren. To fit the uniform resolution, the gridded meteorological data sets were re-projected and resampled to a resolution of $1 \mathrm{~km}$. Besides, in order to further investigate the relationship between human activities and vegetation, we used the statistical data of population, fertilizers, the value of agricultural production, and livestock from the Food and Agriculture Organization of the United Nations (FAO) from 2000 to 2016. These data were preprocessed using the area weighting method for matching study area of FPE. In addition, the aridity and precipitation data used to define the scope of FPE was download from http://www.fao.org/geonetwork/ [34].

\subsection{Methods}

There were four steps to detect the region of vegetation degradation. Step 1, three factors related to vegetation were built, e.g., moisture index (MI), NDVIaccu, and NDVIaccu under unite conditions of MI (MNDVIaccu). Step 2, the changing trend of NDVIaccu and MNDVIaccu were calculated, respectively, using statistics and analyses method of Theil-Sen's trend and MK test. Step 3, the relationship between MNDVIaccu and MI was computed to further acquire the region of no significant change. Step 4, the region of degradation was detected based on the condition and standard of ETheil-Sen-MK for vegetation degradation. In addition, the residual analysis method was used to analyze the anthropogenic contributions on vegetation degradation.

\subsubsection{Statistics and Analyses Method}

The Theil-Sen regression was a non-parametric method and focused on the change of long time series data, which usually easily satisfied the application requirement when measurements were performed by the same instrument and the data followed an underlying model that was close to linear. This was a widely used methodology in environmental time-series data [5,13,35-37]. So, we employed it to calculate the spatial trends (or slope values) of NDVIaccu during the periods of 2000-2016. Theil-Sen's trend $\beta$ is calculated as follows:

$$
\beta=\operatorname{median} \frac{x_{j}-x_{i}}{j-i}
$$

where $1<j<i<n, n$ is the total number of years, $x_{i}$ and $x_{j}$ is the NDVIaccu of $i$ th and $j$ th year. When $\beta>0$, meaning that the trend of the time series data is increasing; when $\beta<0$, the trend of the time series data is decreasing.

Statistical significance is defined by the $p$-value of a MK test [38,39]. A significant difference is attained when the observed $p$-value is less than 0.05 (the significance level). Conversely, when the $p$-value is greater than 0.05 , the difference is of no statistical significance.

In order to investigate the relationship between the change tendency of vegetation and driving factors, we used the Pearson correlation coefficient which was sensitive to a linear relationship between two continuous variables with the normal distribution. The value of Pearson correlation is between $[-1,1]$, the larger the value, the stronger the relationship between vegetation and driving factors, the positive value indicates positive correlation, and the negative value means negative correlation. The formula is:

$$
r_{x y}=\frac{\sum_{i=1}^{n}\left(x_{i}-\bar{x}\right)\left(y_{i}-\bar{y}\right)}{\sqrt{\sum_{i=1}^{n}\left(x_{i}-\bar{x}\right)^{2} \times \sum_{i=1}^{n}\left(y_{i}-\bar{y}\right)^{2}}}
$$

where $r_{x y}$ is the correlation coefficient between NDVIaccu and climatic variables, $x_{i}$ represents the NDVIaccu value of the $i$ th year, $y_{i}$ represents the climatic variables of the $i$ th year, and $\bar{x}, \bar{y}$ represent the averages of NDVIaccu and climatic variables, respectively. $r_{x y}>0$ means that NDVIaccu and the influencing factor are positively correlated, and $r_{x y}<0$ indicates a negative correlation between 
NDVIaccu and the influencing factors. The significance of $r_{x y}$ can be found from the correlation coefficient threshold table.

\subsubsection{Vegetation Degradation Detection}

Generally, a significant reduction in the value of NDVIaccu indicates vegetation degradation, but how is vegetation degradation monitored when vegetation NDVIaccu shows nonsignificant feature but with high trends of decrease? Referring to the work of Sun et al. [40], from the areas where NDVIaccu was not significantly changed, we can further extract the degradation region based on ETheil-Sen-MK by synthesizing the parameters of NDVIaccu, MNDVIaccu and MI. They are defined and constructed as follows:

$$
\begin{aligned}
\mathrm{MI} & =\frac{\mathrm{P}}{\mathrm{PE}} \\
\mathrm{NDVI}_{\mathrm{accu}} & =\sum_{i=5}^{10} \mathrm{NDVI}_{i} \\
\mathrm{MNDVI}_{\mathrm{accu}} & =\frac{\mathrm{NDVI}_{\mathrm{accu}}}{\mathrm{MI} \times 100}
\end{aligned}
$$

where, NDVIaccu is the growing season from May to October annual cumulative NDVI value and $\mathrm{NDVI}_{i}$ is the $i$ th month NDVI value, MI is the annual moisture index, MNDVIaccu is NDVIaccu under unite conditions of MI, $\mathrm{P}$ is the precipitation, and $\mathrm{PE}$ is the potential evaporation. $\mathrm{P}$ and $\mathrm{PE}$ are resampled to the same spatial resolution as the NDVI data, i.e., $1 \mathrm{~km}$.

There are two types of vegetation degradation states including significant degradation and fluctuation degradation. Significant degradation means that NDVIaccu decreased significantly, and MNDVIaccu and MI show a significant negative correlation. Fluctuation degradation indicates that NDVIaccu did not change significantly, but MNDVIaccu decreased significantly or there was a nonsignificant change, and MNDVIaccu and MI show negative correlation. In addition, if NDVIaccu

\begin{tabular}{|c|c|c|c|c|c|}
\hline \multicolumn{3}{|c|}{ Indicators and Trends } & \multicolumn{3}{|c|}{ NDVIaccu } \\
\hline & & & $\begin{array}{c}\text { Significant } \\
\text { Decrease }\end{array}$ & $\begin{array}{c}\text { Not } \\
\text { Significant }\end{array}$ & $\begin{array}{l}\text { Significant } \\
\text { Increase }\end{array}$ \\
\hline \multirow{5}{*}{ MNDVIaccu } & $\begin{array}{l}\text { Significant } \\
\text { decrease }\end{array}$ & $\begin{array}{c}\text { Significant } \\
\text { negatively } \\
\text { correlated with MI }\end{array}$ & $\begin{array}{l}\text { Significant } \\
\text { degradation }\end{array}$ & $\begin{array}{l}\text { Fluctuation } \\
\text { degradation }\end{array}$ & No degradation \\
\hline & & Others & $\begin{array}{c}\text { Significant } \\
\text { degradation }\end{array}$ & $\begin{array}{c}\text { Significant } \\
\text { degradation }\end{array}$ & No degradation \\
\hline & \multicolumn{2}{|c|}{ No significant } & $\begin{array}{c}\text { Significant } \\
\text { degradation }\end{array}$ & $\begin{array}{l}\text { Fluctuation } \\
\text { degradation }\end{array}$ & No degradation \\
\hline & \multirow[t]{2}{*}{$\begin{array}{l}\text { Significant } \\
\text { increase }\end{array}$} & $\begin{array}{c}\text { Significant } \\
\text { negatively } \\
\text { correlated with MI }\end{array}$ & $\begin{array}{c}\text { Significant } \\
\text { degradation }\end{array}$ & $\begin{array}{l}\text { Fluctuation } \\
\text { degradation }\end{array}$ & No degradation \\
\hline & & Others & $\begin{array}{c}\text { Significant } \\
\text { degradation }\end{array}$ & No degradation & No degradation \\
\hline
\end{tabular}
increased positively, the vegetation would show no degradation (Table 1).

Table 1. Monitoring standard of ETheil-Sen-MK for vegetation degradation [40].

\subsubsection{Residual Trend Analysis}

The residual analysis method was used to divide human-induced NDVIaccu (also termed residual NDVIaccu, RNDVIaccu) and climate-based NDVIaccu (termed potential NDVIaccu, PNDVIaccu) from satellite-based observed NDVIaccu [41]. The method was based on the assumption that vegetation growth was caused mainly by climate change, and it was the impact of human activities on vegetation after segregating the climatic factors. 
Due to the linear model can only show independent contributions and superimposed relationship between the variables. However, precipitation and temperature should tend to interact with vegetation. In order to reflect the interaction effect between precipitation, temperature and PNDVIaccu, the quadratic polynomial regression model was employed in our model. At the pixel scale, using assembled annual average temperature $(\mathrm{T})$ and annual total precipitation $(\mathrm{P})$ values in the period 2000-2016, PNDVIaccu model was then constructed. Based on PNDVIaccu, the RNDVIaccu can be easily simulated. Specifically, the method is given as follows:

$$
\begin{gathered}
\text { PNDVIaccu }=\mathrm{a}_{0}+\mathrm{a}_{1} \times \mathrm{T}^{2}+\mathrm{a}_{2} \times \mathrm{P}^{2}+\mathrm{a}_{3} \times \mathrm{T} \times \mathrm{P}+\mathrm{a}_{4} \times \mathrm{T}+\mathrm{a}_{5} \times \mathrm{P} \\
\text { RNDVIaccu }=\text { NDVIaccu }- \text { PNDVIaccu }
\end{gathered}
$$

where $\mathrm{a}_{0} \sim \mathrm{a}_{5}$ are the regression coefficients. Specifically, this study employed the least squares method to obtain the regression coefficients of each pixel [30,42]. The RNDVIaccu residual trend changes denote vegetation changes resulting from human disturbance. Positive residual values indicate that human activities have a positive effect on vegetation changes, while negative values indicate a corresponding negative effect.

\section{Results and Analysis}

In this part, vegetation degradation were investigated based on two methods of Thiel-Sen-MK and ETheil-Sen-MK and the difference in results between them were compared. Then we discussed the relationship between NDVIaccu and precipitation, temperature, evaporation and moisture index. In addition, the effect of human disturbance on vegetation was analyzed.

\subsection{Monitoring of Vegetation Degradation}

As the total NDVI value for May to October each year in the northern hemisphere, NDVIaccu indicates the state of vegetation growth. The Theil-Sen's trends result of NDVIaccu from 2000 to 2016 are shown in Figure 2. Approximately $74.11 \%$ of the grid cells show significant $(p<0.05)$ increasing trends, including the border region between Russia and Kazakhstan, the surrounding areas of the China-Central Asia-West Asia Economic Corridor, most of North Africa, and parts of Iran. Only about $1.64 \%$ of the cells showed significant $(p<0.05)$ decreasing trends, mainly over parts of Russia and Kyrgyzstan.

The NDVIaccu showed significant $(p<0.01)$ upward trend over FPE, with increasing rate of 0.70 per decade during 2000-2016, which was consistent with the values for global vegetation activities reported previously $[20,43]$. The increasing rate was more noticeable after 2009 (trend $=0.96$ or $1.70 \%$ per decade, $p<0.01$ ) than prior to that (trend $=0.26$ or $1.10 \%$ per decade, $p<0.01$ ). The increasing trends of grassland NDVIaccu and cropland NDVIaccu are showed in Figure S1, which was synchronized with NDVIaccu over FPE, reaching their lowest value in 2009. But the higher cropland NDVIaccu value indicated a greater contribution than grassland NDVIaccu under the same conditions of increasing trend.

From figure of identification of vegetation degradation during 2000-2016 (Figure 3), we found that the area of degraded vegetation was $4.83 \times 10^{5} \mathrm{~km}^{2}$ (about 25.43\%) during 2000-2016. Approximately $21.29 \%$ of the grid cells showed significant $(p<0.05)$ degradation, which signified that more than $19.65 \%$ degradation zone was concealed by Theil-Sen's trend results (Figure 2). About $4.14 \%$ of the cells showed fluctuant degradation, mainly over the border region between Russia and Kazakhstan. 


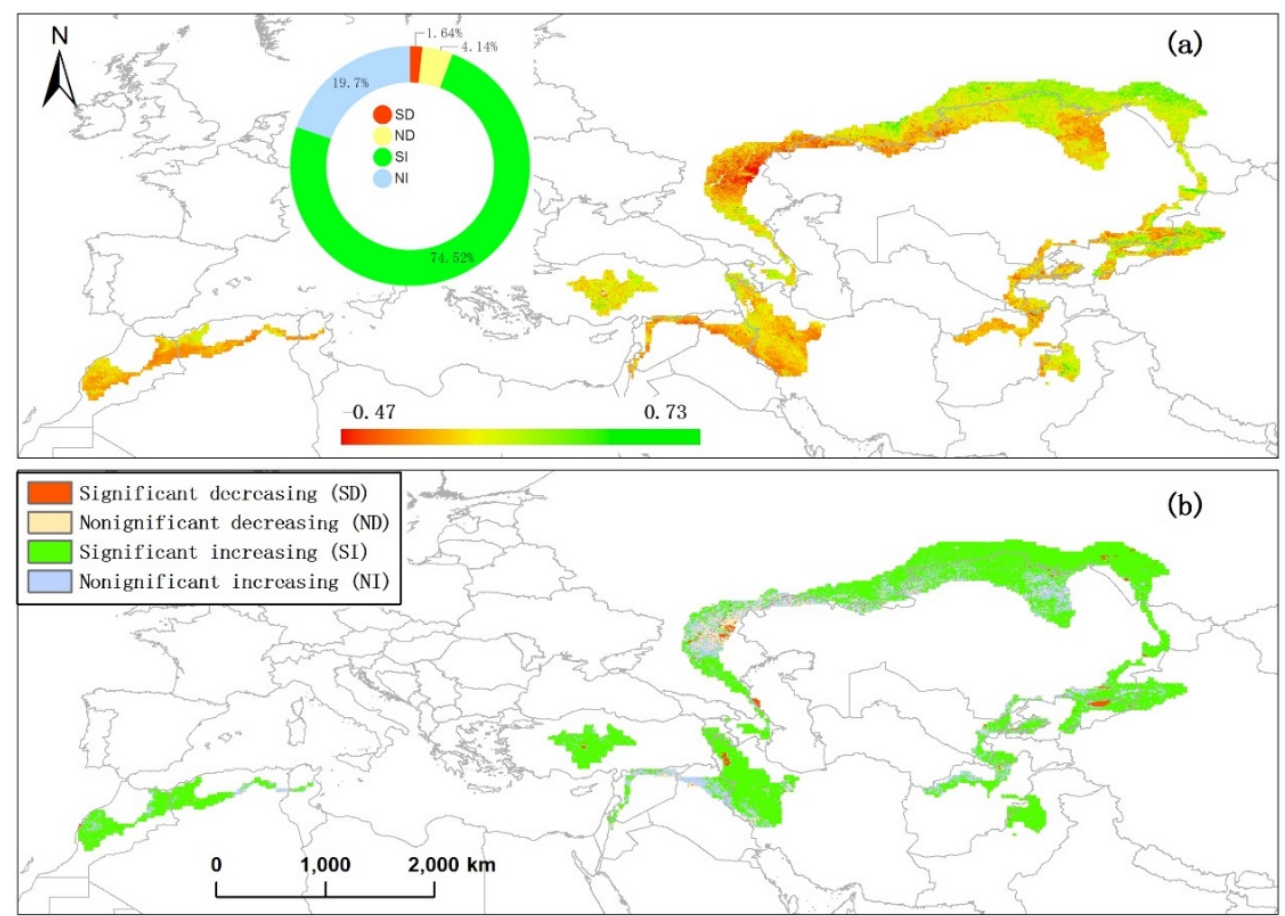

Figure 2. NDVIaccu changing trends and significance levels: (a) NDVIaccu changing trends; (b) Trends significant at the 0.05 level.

Typical regions of vegetation degradation mainly appeared in the New Continental Bridge Economic Corridor, the largest scope of significant degradation occurred in the border region between Russia and Kazakhstan (4.78\%). Syria in the eastern Mediterranean, as well as Iraq in the southern part of the China-Central Asia-West Asia Economic Corridor had also incurred significant degradation (3.17\%). In addition, the north of part of Kazakhstan degraded by $2.31 \%$ (Figure 3, Table 2).

From the figure of vegetation degradation of different vegetational types (Figures S2 and S3), we knew that cropland $(10.03 \%)$ was the main type of degradation, followed by desert vegetation $(4.00 \%)$ and grassland (3.71\%) in the FPE during 2000-2016. From the perspective of three typical regions, $5.46 \%$ of cropland area depredated, which was larger than grassland $(2.32 \%)$. Specifically, $1.05 \%, 3.19 \%$ and $1.22 \%$ of cropland depredated in region 1, region 2 and region3, respectively. However, depredated desert vegetation (1.68\%) was larger than cropland in region 3. 
Table 2. Statistics of the vegetation degradation in typical area.

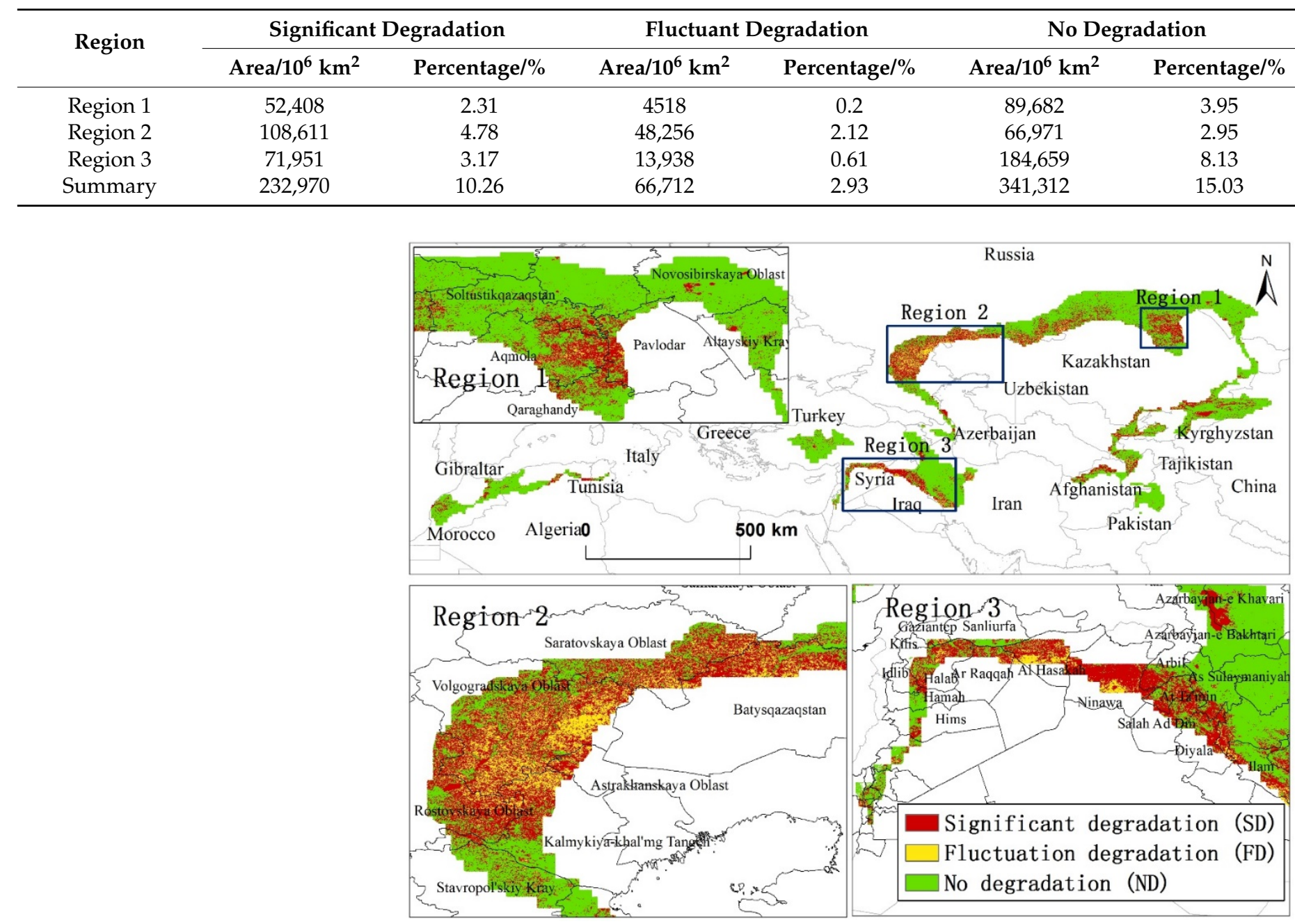

Figure 3. Identification of vegetation degradation during 2000-2016. 


\subsection{Vegetation Degradation Under the Impact of Climate Conditions}

Analysis of the Figure $\mathrm{S} 4$ of the changes of $\mathrm{P}, \mathrm{T}$ and PE showed that the annual $\mathrm{P}$ ( $377 \mathrm{~mm}$ ) was higher than PE (40 mm) in the period 2000-2016. During the 17 years, T, P, and PE in the growing season record that most FPEs showed rapidly increased $\mathrm{T}$, moderately increased $\mathrm{P}$, and consistently increased PE at the 0.05 significance level. Furthermore, the increasing trend of $\mathrm{P}(1.58 \mathrm{~mm} / \mathrm{a})$ was greater than that of PE $(0.04 \mathrm{~mm} / \mathrm{a})$ (Figure S4). Therefore, the moisture index controlled by P and PE also increased. The rate of increasing in $\mathrm{T}$ in this area was $0.18^{\circ} \mathrm{C}$ per decade, slightly lower than the global average $\left(\sim 0.20^{\circ} \mathrm{C}\right.$ per decade) [44].

The Figure S5a of the changes of NDVIaccu under disparate scenario of $\mathrm{P}$ showed that the changes of NDVIaccu were discrepant under a disparate scenario of variations in P in FPE, but it was an evidently positive relationship. NDVIaccu increased significantly, while P increased moderately. However, NDVIaccu decreased significantly, while P decreased slightly (Figure S5a). Figure 4 shows the correlation coefficients between NDVIaccu and P during 2000-2016. These correlations revealed that the coupling intensity of the interannual variations. A total of $76.07 \%$ of regions showed significant positive correlations, and 3.92\% displayed a negative relationship $(p<0.05)$ between NDVIaccu and $\mathrm{P}$.

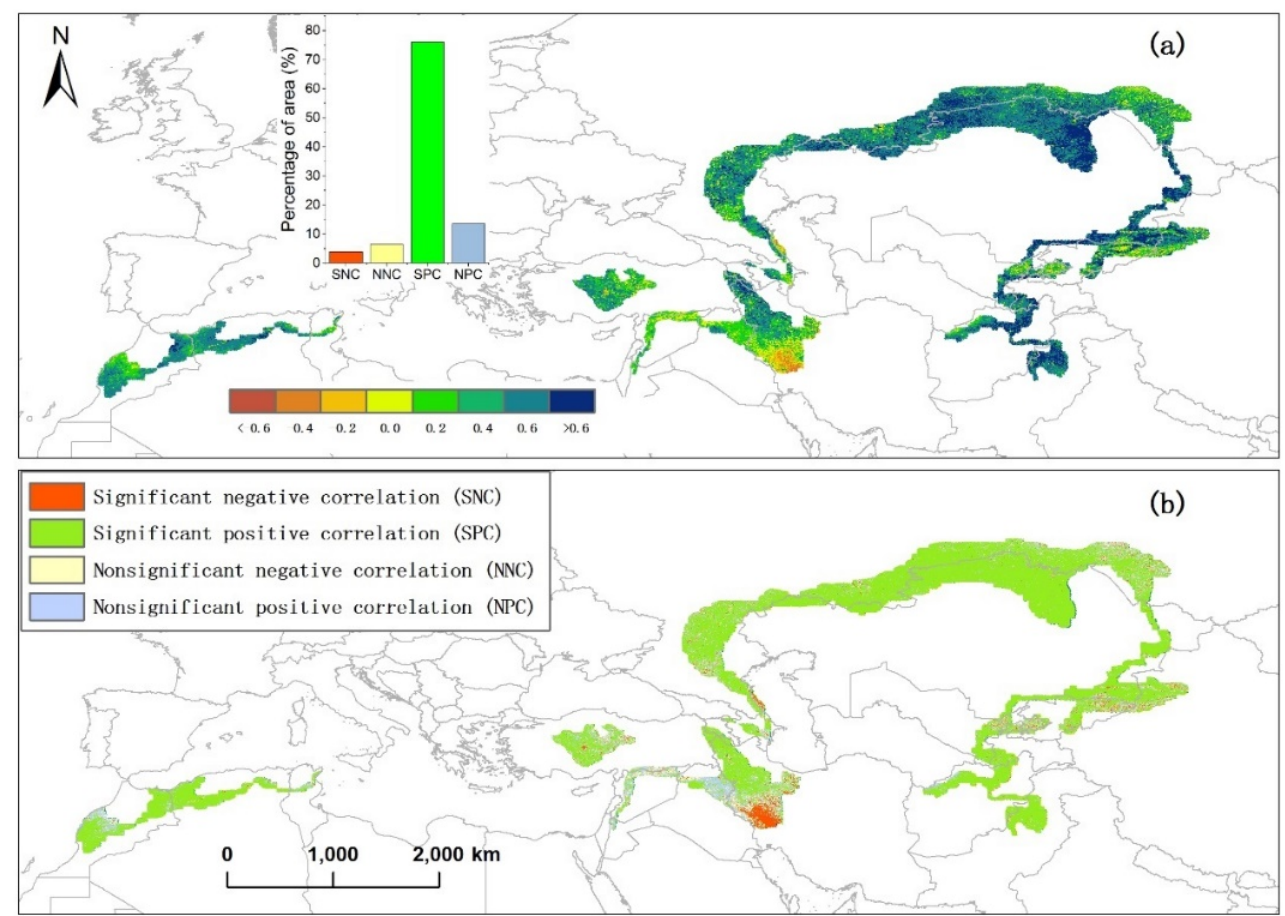

Figure 4. Correlation coefficients between NDVIaccu and precipitation: (a) Correlation coefficient; (b) Correlations significant at the 0.05 level.

The Figure S5b of changes of NDVIaccu under disparate scenario of temperature showed that the correlations between NDVIaccu and temperature were complex in the context of diversely increased intensity in T. Against a background of weakly increasing trends for T, NDVIaccu showed a significant increasing trend, whereas for strongly increasing trends for $\mathrm{T}$, NDVIaccu displayed a significant decreasing trend (Figure S5b). From Figure 5, we acquired that a total of $42.56 \%$ of NDVIaccu was negatively correlated with $\mathrm{T}$ across the border region between Russia and Kazakhstan, and $34.16 \%$ of the region showed significant positive correlations between NDVIaccu and T $(p<0.05)$, which were found at relatively high northern latitudes in Kazakhstan and in the western and eastern areas of the Mediterranean, indicating that vegetation growth over these areas was T-controlled (Figure 5). 


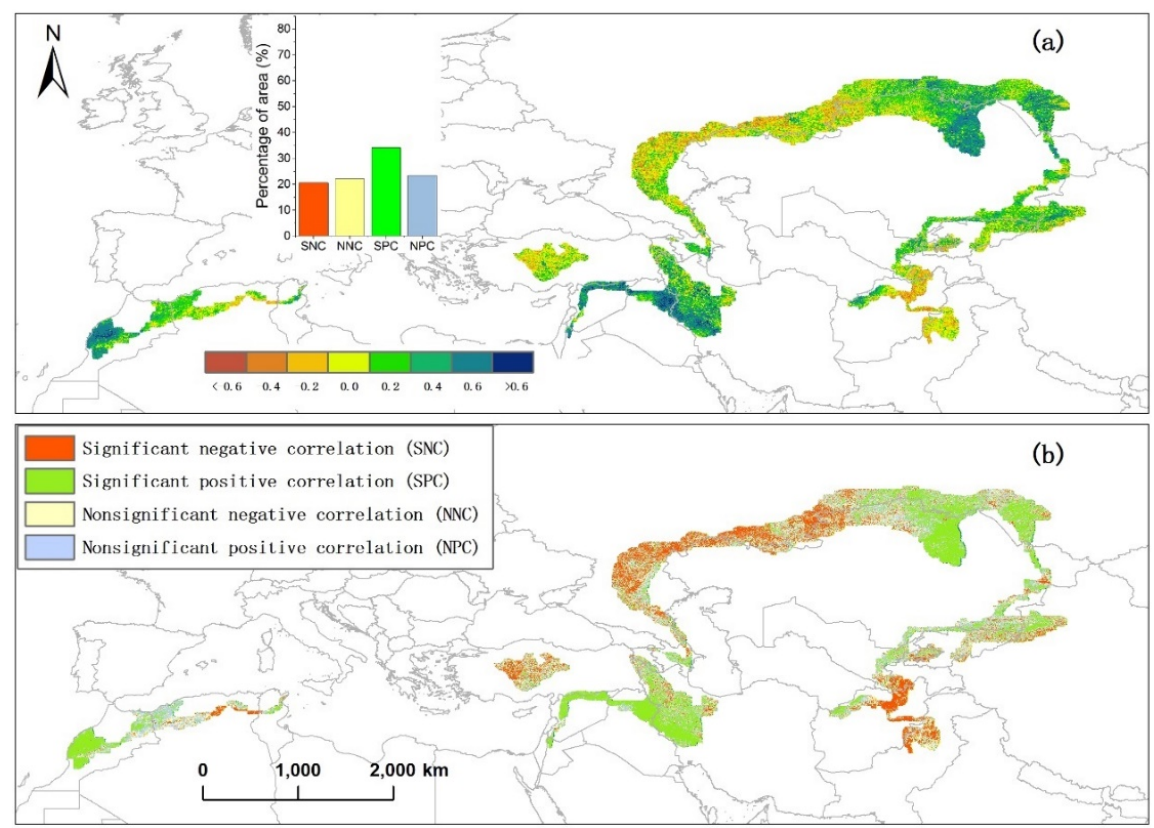

Figure 5. Correlation coefficients between NDVIaccu and temperature: (a) Correlation coefficient;

(b) Correlations significant at the 0.05 level.

From Figure 6, we confirm the notion that water was the limiting factor for vegetation growth in arid and semi-arid regions [45], where $\mathrm{T}$ increased as the surface dries up, leading to negative NDVIaccu-T correlations. A total of $44.56 \%$ of area NDVIaccu showed significant positive correlations between NDVIaccu and MI, and the correlation coefficients in most of the region were medium to low ( 0.50) (Figure 6), mainly including the border region between Russia and Kazakhstan. A total of $43.42 \%$ of the cells were also positively correlated between NDVIaccu and MI, but the correlation was not significant $(p>0.05)$, covering pars of the eastern and western Mediterranean and North Africa. NDVIaccu also showed significant increasing trends in this region.

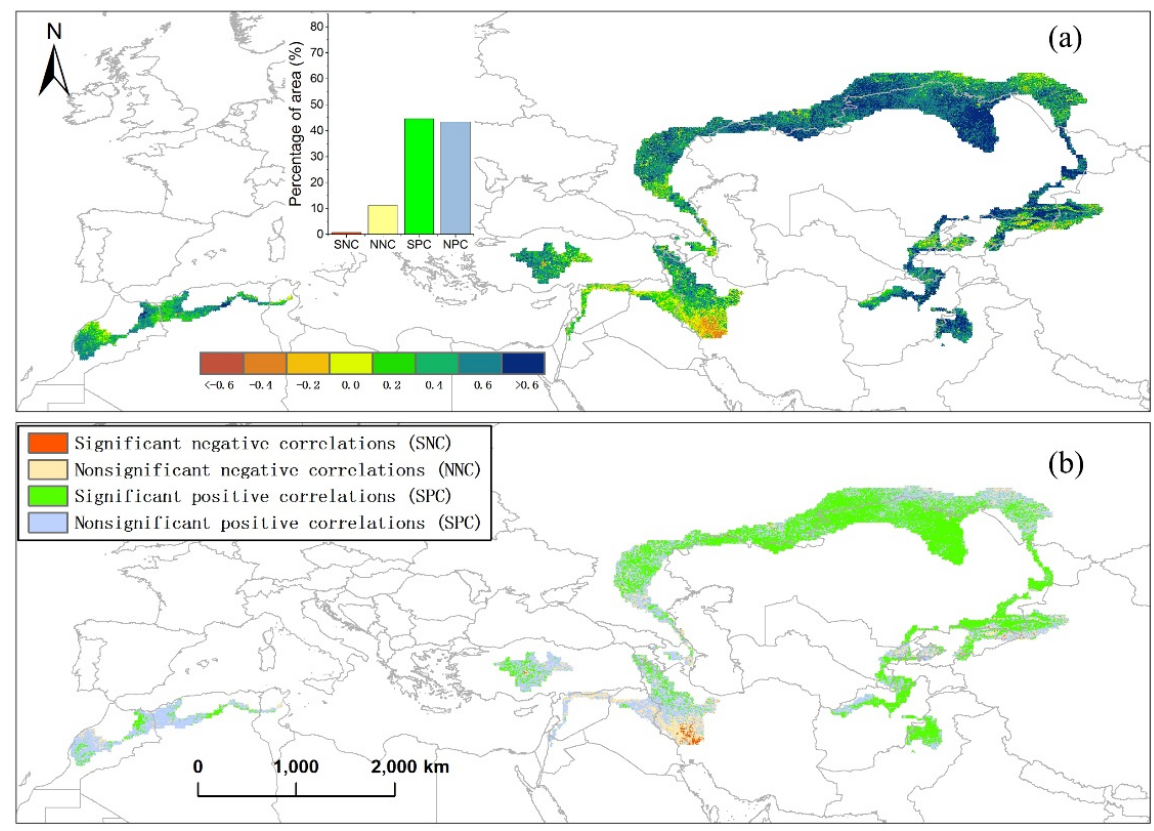

Figure 6. Correlation coefficients between NDVIaccu and moisture index: (a) Correlation coefficients; (b) Correlations significant at 0.05 level. 


\subsection{The Effect of Human Disturbance on Vegetation Degradation}

Figure 7 shows that averaged RNDVIaccu was 0.37 for the entire study area, suggesting that human activities had a positive effect at the regional scale. In addition, the annual RNDVIaccu showed similar characters of increasing trend with that of annual NDVIaccu at the corresponding period (Figure S6), demonstrating the major role of trends of RNDVIaccu for trends of NDVIaccu $(0.07, p<0.000)$. Nevertheless, PNDVIaccu trend decreased significantly $\left(-0.02 \times 10^{-4}, p=0.006\right)$, which indicated an inverse trend with NDVIaccu, implying that climate factors had less influence on the change of vegetation.

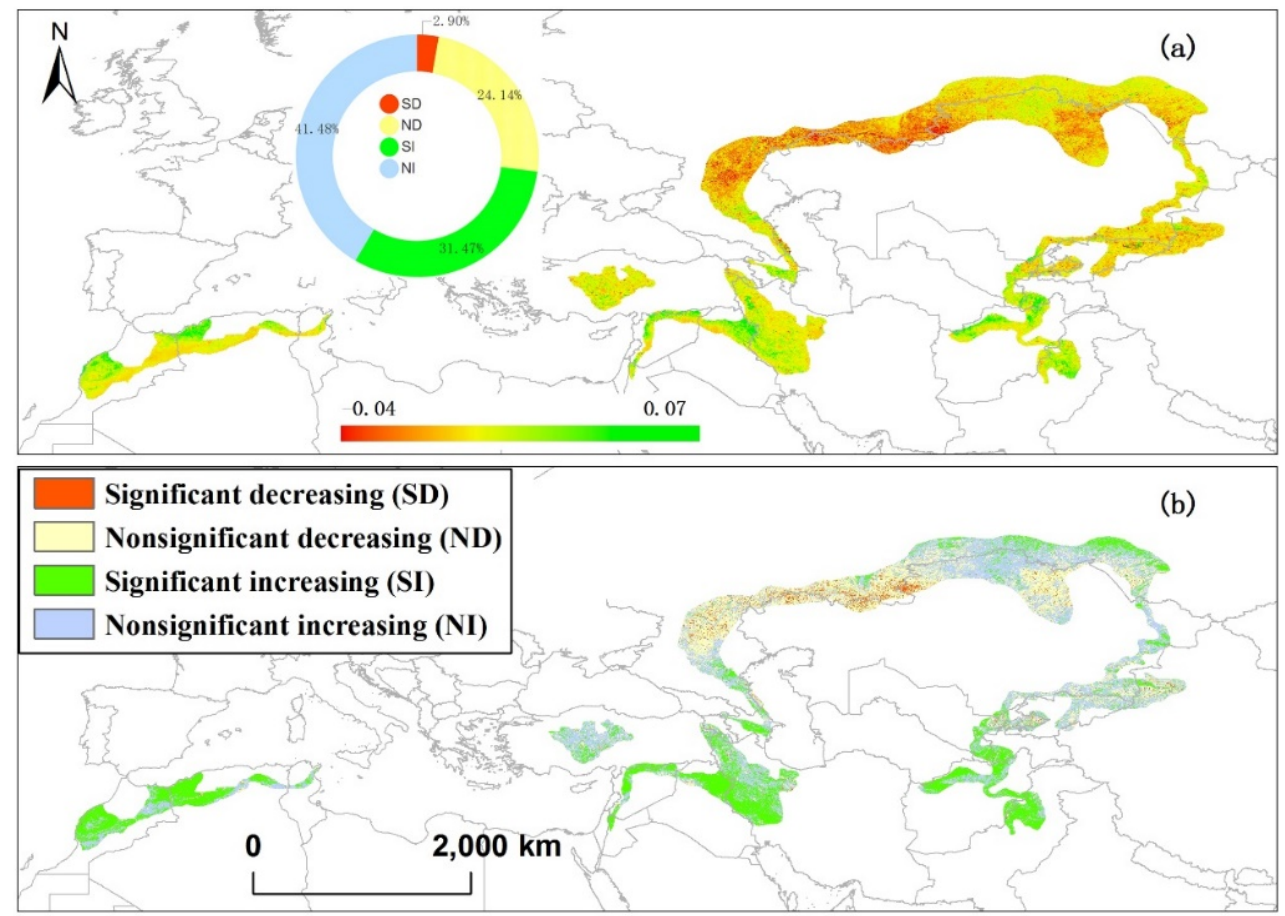

Figure 7. RNDVIaccu changing trends and significance levels: (a) RNDVIaccu changing trends;

(b) Trends significant at 0.05 trends.

From the RNDVIaccu changing trends (Figure 7), we knew that trends in RNDVIaccu showed similar spatial distributions with NDVIaccu during the corresponding period 2000-2016, suggesting a major role for trends in RNDVIaccu. For 17-year period, the RNDVIaccu of most regions $(31.47 \%)$ indicated significant increased trends, including most parts of the eastern and western Mediterranean $(p<0.05)$. There were some regions with negative trends, concentrated mainly on the border region between Russia and Kazakhstan. However, the trends for most regions were nonsignificant $(p>0.05)$. Regions with significantly decreased trends accounted for only $2.90 \%$ of the entire study area. These significantly decreased pixels were centralized across the border areas of Russia and Kazakhstan in the southwestern part of the New Continental Bridge Economic Corridor (Figure 7).

Overlying the land use type and RNDVIaccu (Figure S7), we knew that NDVIaccu impacted by human activities mainly owing to cropland. Further founding was that $1.82 \%$ of NDVIaccu decreasing be attributed to cropland area reduction and $12.05 \%$ of NDVIaccu increasing be due to fertilizer increasing (Figure S8, Table S1). In addition, grassland NDVIaccu may also be affected by anthropogenic activities, and ended up with $0.65 \%$ decreasing and $3.41 \%$ increasing (Figure S7), which is most likely related to increase of livestock and grassland area (Figure S8, Table S1).

\section{Discussion}

The FPE is a spatial domain in which the main behavior and structural characteristics of the system are "bursting" during the transition zone between the two ecosystems of cropland and grassland [20,43]. 
Vegetation changes were particularly susceptible to climate factors in FPE $[19,20,46]$. T, P, and PE in the growing season recorded that most FPEs rapidly increased in T, moderately increased in $\mathrm{P}$, and consistently increased in PE during the 17 years (Figure S4). Increasing trends of $\mathrm{T}$ and $\mathrm{P}$ in FPEs can induce much stronger plant evaporation and soil transpiration [47]. Trends in PE likely result in insufficient soil moisture supplement, which further affects vegetation growth to some extent. Furthermore, under disparate scenarios of variations in $\mathrm{P}$ and $\mathrm{T}$, the changes in NDVIaccu were discrepant, and both $\mathrm{T}$ and $\mathrm{PE}$ move in a direction that was not conducive to vegetation activities (Figure S4).

P displayed strong correlations with NDVIaccu, and $76.07 \%$ of region displayed significant positive correlations between NDVIaccu and P over entire FPE. In contrast, the statistic results of the relationship between the NDVIaccu and T indicated that $42.56 \%$ regions of FPE were negative correlations, and $34.16 \%$ regions of FPE were positive correlations, suggesting the relationship between NDVIaccu and $T$ varied with complex topography, climate conditions, and vegetation types.

Furthermore, for increasing T, in contrast, NDVIaccu showed a significant decreasing trend. This could be due to the fact that the impact of warming $T$ varies depending on regional differences. In cold regions, moderate warming was conducive to vegetation vigor, but in arid or high $\mathrm{T}$ regions, warming may be inimical to vegetation activities.

Comparing the contributions of climate and anthropogenic activities on vegetation, we analyzed the trends in PNDVIaccu and RNDVIaccu, which indicate that the comprehensive effects of current climate change had only relatively little contributions to vegetation greening or degradation trends in general, but anthropogenic activities oriented the changing trend of vegetation. Other studies of specific regions also supported our findings [48]. Previous studies from some other regions stated that vegetation growth was mainly controlled by climatic fluctuations and human activities $[12,49,50]$. Quantifying the contribution of each driving factor was thus crucial for understanding their relative importance for determining changes in regional vegetation cover. In this study, we have found that mainly anthropogenic contributions dominate the greening and degradation trends of NDVIaccu in FPEs. Note that RNDVIaccu in most FPEs, especially in western and southeastern FPEs, showed significantly increasing trends $(p<0.05)$, suggesting that human activities played a positive role in vegetation changes in these regions. From Figure S1, the average NDVIaccu of cropland continues to increase, and population, fertilizers and the value of agricultural production all showed a significant increasing trend and positive relationship with NDVIaccu in FPEs (Table S1). Therefore, agricultural activities made the greatest contribution to the greening of vegetation. Most notably, $4.78 \%$ of the grid cells maintain significant degradation, including mainly the border region between Russia and Kazakhstan, where RNDVIaccu also showed decreasing trends (2.90\% significant decrease and $24.14 \%$ nonsignificant decrease), which was likely related to unreasonable anthropogenic activities for cropland use, causing the continuous decreasing in cropland area (Figure S8). Besides, many previous studies have reported that livestock grazing can remove biomass by means of the long-term destruction of grassland [32]. The degradation of vegetation was mainly related to increases in the numbers of livestock (Table S1), especially in Pakistan.

On the whole, under the coupled effects of climate factors and human activities in FPEs, $21.29 \%$ of vegetation degraded, which was more serious than the global average level of vegetation degradation of $8 \%$ [20]. Therefore, extraordinary attention should be paid to the areas of vegetation that showed significant degradation in the border region between Russia and Kazakhstan. Against the background of mitigation of increases in $\mathrm{P}$ and acceleration of increases in $\mathrm{T}$, we should pay more attention to ecological environment protection in areas affected by $\mathrm{P}$ and $\mathrm{T}$ and minimize the negative impact of human factors on the ecological environment. Such measures would include using the land rationally according to its suitability for different functions, limiting the growth of artificial land, halting the reduction in natural vegetation and water bodies, and focusing on preventing the intensive use of agricultural land and its associated ecological problems such as agricultural nonpoint source pollution. 
In addition, it should be noted that there are clearly some flaws in the climate-based NDVIaccu model since it was difficult to determine the regions that are completely unaffected by human disturbance and to separate out the years in which no anthropogenic activity happens. Therefore, the PNDVIaccu prediction model proposed in this paper was based on the entire study region for the period from 2000 to 2016, which must result in estimation error. Furthermore, the effect of human activities and climate factors on NDVIaccu was not a simple linear relationship as our hypothesis in the residual analysis; therefore, we need to explore their complex relationships and mechanisms in the further work. Besides, the impact of light plays a key role in vegetation activities by affecting plant photosynthesis [20]. Thus, we need to comprehensively consider the interactions of light, temperature, and water over the course of a more restricted period in further analysis.

\section{Conclusions}

We have found that NDVIaccu showed enhanced trends in FPEs during 2000-2016, and only $1.64 \%$ of the areas with significantly reduced NDVIaccu. However, $30 \%$ significant degradation occurred based on ETheil-Sen-MK and $21.29 \%$ of area vegetation showed significant degradation in the border region between Russia and Kazakhstan over the periods 2000-2016. Therefore, more than $19.65 \%$ degradation area was overlooked by Theil-Sen's trend as for no significance omit.

The relationship between P and NDVIaccu was straightforward and NDVIaccu was sensitive and responsive in the face with the change of precipitation. There was $76.07 \%$ of region displayed significant positive correlation. However, correlations between NDVIaccu and T varied with complex topography, climate conditions, and land use types. For instance, negative correlations observed across the border region between Russia and Kazakhstan. However, correlation between vegetation growth and $\mathrm{T}$ was found to be positive in relatively high latitudes in the western and eastern areas of the Mediterranean.

In addition, trends in PNDVIaccu indicated that the comprehensive effect of current climate change had less impact on vegetation change and NDVIaccu increasing trends were primarily attributable to anthropogenic forcing (direct or indirect). The RNDVIaccu of most regions $(31.47 \%)$ indicated significant increasing trends, which were driven mainly by cropland NDVIaccu affected by human activities and economic factors such as population, agricultural fertilization, and the value of agricultural production. A few areas in Kazakhstan showed a negative effect of anthropogenic activities, which was likely related to unreasonable anthropogenic activities for cropland use, causing the continuous decreasing in cropland area and decreasing in grassland NDVIaccu as a result of an increase in the intensity of grazing by livestock.

By investigating the extent of vegetation degradation and its driver factors in FPE over the countries along BRI, we found that the degree of vegetation degradation of this fragile area was more serious than the global average level, thence we suggest that in the implementation of BRI in the future over this region, more attention should be paid to the ecological environment, especially for $21.29 \%$ of degraded vegetation region. For areas where human activities have had significant negative effects $(2.90 \%)$, further specific reasons need to be found out to help us use the land rationally according to its suitability for different functions.

Supplementary Materials: The following are available online at http:/ /www.mdpi.com/2071-1050/11/6/1590/s1, Figure S1: Changes of FPE NDVIaccu, cropland NDVIaccu and grassland NDVIaccu, Figure S2: Vegetation degradation of different land use types, Figure S3: Vegetation degradation of different land use types in typical region, Figure S4: Changes of precipitation, temperature and potential evaporation, Figure S5: Changes of NDVIaccu under disparate scenario disparate scenario of precipitation (a) and temperature (b), respectively, Figure S6: Changes of NDVIaccu, PNDVIaccu and RNDVIaccu, Figure S7: The impact of RNDVIaccu on different vegetational types, Figure S8: Area change of cropland and grassland, Table S1: The Change trends of population, agricultural production and fertilizer in FPE.

Author Contributions: Q.L. designed, performed the study, processed and analyzed the data and wrote the manuscript. Y.Z. and X.W. came up with the conception and assisted with the suggestion of the study area, insights on the revision of the manuscript and suggestions for improvement. H.Z. and L.L. assisted to processed 
and analyzed the satellite time series. All authors participated in writing the final version of the manuscript, and reviewed and approved it.

Funding: This study was supported by the Strategic Priority Research Program of the Chinese Academy of Sciences (Grant No. XDA20000000) and Global Ecosystems and Environment Observation Analysis Research Cooperation (Grant No. 1061302600001).

Acknowledgments: The authors are grateful for the data provider of MOD13A3 NDVI, CRU data, ESA land use data and we would like to thank the anonymous reviewers for providing valuable feedback and suggestions. Thanks especially to Prof. Xiaohan Liao, Prof. Jiyuan Liu and Dr. Yaohuan Huang of IGSNRR for their continuing advice.

Conflicts of Interest: The authors declare no conflict of interest.

\section{References}

1. Johnson, D.L.; Lewis, L.A. Land Degradation: Creation and Destruction; Rowman \& Littlefield: Lanham, MD, USA, 2006.

2. Bullock, E.L.; Woodcock, C.E.; Olofsson, P. Monitoring tropical forest degradation using spectral unmixing and Landsat time series analysis. Remote Sens. Environ. 2018. [CrossRef]

3. D'Odorico, P.; Bhattachan, A.; Davis, K.F.; Ravi, S.; Runyan, C.W. Global desertification: Drivers and feedbacks. Adv. Water Resour. 2013, 51, 326-344. [CrossRef]

4. Sommer, S.; Zucca, C.; Grainger, A.; Cherlet, M.; Zougmore, R.; Sokona, Y.; Hill, J.; Della Peruta, R.; Roehrig, J.; Wang, G. Application of indicator systems for monitoring and assessment of desertification from national to global scales. Land Degrad. Dev. 2011, 22, 184-197. [CrossRef]

5. Sun, B.; Li, Z.; Gao, Z.; Guo, Z.; Wang, B.; Hu, X.; Bai, L. Grassland degradation and restoration monitoring and driving forces analysis based on long time-series remote sensing data in Xilin Gol League. Acta Ecol. Sin. 2017, 37, 219-228. [CrossRef]

6. Zhang, G.; Biradar, C.M.; Xiao, X.; Dong, J.; Zhou, Y.; Qin, Y.; Zhang, Y.; Liu, F.; Ding, M.; Thomas, R.J. Exacerbated grassland degradation and desertification in Central Asia during 2000-2014. Ecol. Appl. 2018, 28, 442-456. [CrossRef] [PubMed]

7. Sarkar, S.; Kafatos, M. Interannual variability of vegetation over the Indian sub-continent and its relation to the different meteorological parameters. Remote Sens. Environ. 2004, 90, 268-280. [CrossRef]

8. Stavi, I.; Lal, R. Achieving Zero Net Land Degradation: Challenges and opportunities. J. Arid Environ. 2015, 112, 44-51. [CrossRef]

9. Zhang, Y.; Gao, J.; Liu, L.; Wang, Z.; Ding, M.; Yang, X. NDVI-based vegetation changes and their responses to climate change from 1982 to 2011: A case study in the Koshi River Basin in the middle Himalayas. Glob. Planet. Chang. 2013, 108, 139-148. [CrossRef]

10. Fang, J.; Piao, S.; He, J.; Ma, W. Increasing terrestrial vegetation activity in China, 1982-1999. Sci. China Ser. C Life Sci. 2004, 47, 229-240. [CrossRef]

11. Piao, S.; Nan, H.; Huntingford, C.; Ciais, P.; Friedlingstein, P.; Sitch, S.; Peng, S.; Ahlström, A.; Canadell, J.G.; Cong, N.; et al. Evidence for a weakening relationship between interannual temperature variability and northern vegetation activity. Nat. Commun. 2014, 5. [CrossRef] [PubMed]

12. Abbas, G.; Ahmad, S.; Ahmad, A.; Nasim, W.; Fatima, Z.; Hussain, S.; Rehman, M.H.U.; Khan, M.A.; Hasanuzzaman, M.; Fahad, S.; et al. Quantification the impacts of climate change and crop management on phenology of maize-based cropping system in Punjab, Pakistan. Agric. For. Meteorol. 2017, 247, 42-55. [CrossRef]

13. Jiang, W.; Yuan, L.; Wang, W.; Cao, R.; Zhang, Y.; Shen, W. Spatio-temporal analysis of vegetation variation in the Yellow River Basin. Ecol. Indic. 2015, 51, 117-126. [CrossRef]

14. Wang, Z.; Zhang, Y.; Yang, Y.; Zhou, W.; Gang, C.; Zhang, Y.; Li, J.; An, R.; Wang, K.; Odeh, I.; et al. Quantitative assess the driving forces on the grassland degradation in the Qinghai-Tibet Plateau, in China. Ecol. Inform. 2016, 33, 32-44. [CrossRef]

15. Curran, P.J.; Hay, A.M. The importance of measurement error for certain procedures in remote sensing at optical wavelength. Photogramm. Eng. Remote Sens. 1986, 52, 229-241.

16. Sen, P.K. Estimates of the Regression Coefficient Based on Kendall's Tau. Publ. Am. Stat. Assoc. 1968, 63, $1379-1389$. [CrossRef] 
17. Theil, H. A Rank-Invariant Method of Linear and Polynomial Regression Analysis. Nederl. Akad. Wetensch. Proc. 1992, 12, 345-381.

18. Pan, N.; Feng, X.; Fu, B.; Wang, S.; Ji, F.; Pan, S. Increasing global vegetation browning hidden in overall vegetation greening: Insights from time-varying trends. Remote Sens. Environ. 2018, 214, 59-72. [CrossRef]

19. Pei, F.; Wu, C.; Liu, X.; Li, X.; Yang, K.; Zhou, Y.; Wang, K.; Xu, L.; Xia, G. Monitoring the vegetation activity in China using vegetation health indices. Agric. For. Meteorol. 2018, 248, 215-227. [CrossRef]

20. Zhao, L.; Dai, A.; Dong, B. Changes in global vegetation activity and its driving factors during $1982-2013$. Agric. For. Meteorol. 2018, 249, 198-209. [CrossRef]

21. Bala, G.; Caldeira, K.; Wickett, M.; Phillips, T.J.; Lobell, D.B.; Delire, C.; Mirin, A. Combined climate and carbon-cycle effects of large-scale deforestation. Proc. Natl. Acad. Sci. USA 2007, 104, 6550. [CrossRef] [PubMed]

22. Peng, S.S.; Piao, S.; Zeng, Z.; Ciais, P.; Zhou, L.; Li, L.Z.X.; Myneni, R.B.; Yin, Y.; Zeng, H. Afforestation in China cools local land surface temperature. Proc. Natl. Acad. Sci. USA 2014, 111, 2915-2919. [CrossRef] [PubMed]

23. Jiapaer, G.; Chen, X.; Bao, A. A comparison of methods for estimating fractional vegetation cover in arid regions. Agric. For. Meteorol. 2011, 151, 1698-1710. [CrossRef]

24. Yang, F.; Yang, M. Greening the one belt and one road initiative. Mitig. Adapt. Strateg. Glob. Chang. 2018. [CrossRef]

25. Shi, W.; Liu, Y.; Shi, X. Contributions of climate change to the boundary shifts in the farming-pastoral ecotone in northern China since 1970. Agric. Syst. 2018, 161, 16-27. [CrossRef]

26. Zhang, Y.; Wang, X.; Liu, Q.; Wu, X.; Zhang, B.; Zhang, H.; Li, L.; Xie, F. Ecological Environment of Farming-Pastoral Ecotone over the Belt and Road. National remote sensing center of Ministry of Science and Technology of the People's Republic of China. 2018, pp. 3-19. Available online: http:/ / www.chinageoss.org/ geoarc/en/index.html (accessed on 14 March 2019). (in Chinese).

27. The European Space Agency (ESA). Climate Change Initiative Land Cover (CCI LC); ESA: Paris, France, 1992.

28. Kamel, D.; Alfredo, H. MOD13A3: MODIS/Terra Vegetation Indices Monthly L3 Global 1 km SIN Grid V006; NASA EOSDIS Land Processes DAAC: Washington, DC, USA, 2018.

29. Chen, B.; Zhang, X.; Tao, J.; Wu, J.; Wang, J.; Shi, P.; Zhang, Y.; Yu, C. The impact of climate change and anthropogenic activities on alpine grassland over the Qinghai-Tibet Plateau. Agric. For. Meteorol. 2014, 189-190, 11-18. [CrossRef]

30. Liu, J.; Wu, J.; Su, H.; Gao, Z.; Wu, Z. Effects of grazing exclusion in Xilin Gol grassland differ between regions. Ecol. Eng. 2017, 99, 271-281. [CrossRef]

31. Harris, I.; Jones, P.D.; Osborn, T.J.; Lister, D.H. Updated high-resolution grids of monthly climatic observations-The CRU TS3.10 Dataset. Int. J. Climatol. 2014, 34, 623-642. [CrossRef]

32. Mitchell, T.D.; Jones, P.D. An improved method of constructing a database of monthly climate observations and associated high-resolution grids. Int. J. Climatol. 2005, 25, 693-712. [CrossRef]

33. New, M.; Hulme, M.; Jones, P. Representing Twentieth-Century Space-Time Climate Variability. Part II: Development of 1901-96 Monthly Grids of Terrestrial Surface Climate. J. Clim. 2000, 13, 2217-2238. [CrossRef]

34. FAO. FAO Country Statistics; FAO: Rome, Italy, 2018.

35. Gocic, M.; Trajkovic, S. Analysis of changes in meteorological variables using Mann-Kendall and Sen's slope estimator statistical tests in Serbia. Glob. Planet. Chang. 2013, 100, 172-182. [CrossRef]

36. Hou, X.; Wu, T.; Yu, L.; Qian, S. Characteristics of multi-temporal scale variation of vegetation coverage in the Circum Bohai Bay Region, 1999-2009. Acta Ecol. Sin. 2012, 32, 297-304. [CrossRef]

37. Wang, J.; Wang, K.; Zhang, M.; Zhang, C. Impacts of climate change and human activities on vegetation cover in hilly southern China. Ecol. Eng. 2015, 81, 451-461. [CrossRef]

38. Litchfield, J.T.; Wilcoxon, F. Rank Correlation Method. Anal. Chem. 1955, 27, 299-300. [CrossRef]

39. Mann, H.B. Nonparametric tests against trend. Econometrica 1945, 13, 245. [CrossRef]

40. Sun, B. Identification and Assessment of Land Degradation Using Remote Sensing Techniques-A Case Study in Inner Mongolia Autonomous Region; Chinese Academy of Forestry Sciences: Beijing, China, 2016; p. 149.

41. Evans, J.; Geerken, R. Discrimination between climate and human-induced dryland degradation. J. Arid Environ. 2004, 57, 535-554. [CrossRef] 
42. Wang, F.; An, P.; Huang, C.; Zhang, Z.; Hao, J. Is afforestation-induced land use change the main contributor to vegetation dynamics in the semiarid region of North China? Ecol. Indic. 2018, 88, 282-291. [CrossRef]

43. Zhu, Z.; Piao, S.; Myneni, R.B.; Huang, M.; Zeng, Z.; Canadell, J.G.; Ciais, P.; Sitch, S.; Friedlingstein, P.; Arneth, A.; et al. Greening of the Earth and its drivers. Nat. Clim. Chang. 2016, 6, 791-795. [CrossRef]

44. Marotzke, J.; Forster, P.M. Forcing, feedback and internal variability in global temperature trends. Nature 2015, 517, 565-570. [CrossRef] [PubMed]

45. Nemani, R.R.; Keeling, C.D.; Hashimoto, H.; Jolly, W.M.; Piper, S.C.; Tucker, C.J.; Myneni, R.B.; Running, S.W. Climate-Driven Increases in Global Terrestrial Net Primary Production from 1982 to 1999. Science 2003, 300, 1560. [CrossRef] [PubMed]

46. Li, Q.; Zhang, C.; Shen, Y.; Jia, W.; Li, J. Quantitative assessment of the relative roles of climate change and human activities in desertification processes on the Qinghai-Tibet Plateau based on net primary productivity. Catena 2016, 147, 789-796. [CrossRef]

47. Liu, Z.; Liu, Y.; Li, Y. Anthropogenic contributions dominate trends of vegetation cover change over the farming-pastoral ecotone of northern China. Ecol. Indic. 2018, 95, 370-378. [CrossRef]

48. Wang, Y.; Yan, X. Climate change induced by Southern Hemisphere desertification. Phys. Chem. Earth Parts $A / B / C$ 2017, 10, 40-47. [CrossRef]

49. Leroux, L.; Bégué, A.; Lo Seen, D.; Jolivot, A.; Kayitakire, F. Driving forces of recent vegetation changes in the Sahel: Lessons learned from regional and local level analyses. Remote Sens. Environ. 2017, 191, 38-54. [CrossRef]

50. Qu, S.; Wang, L.; Lin, A.; Zhu, H.; Yuan, M. What drives the vegetation restoration in Yangtze River basin, China: Climate change or anthropogenic factors? Ecol. Indic. 2018, 90, 438-450. [CrossRef]

(C) 2019 by the authors. Licensee MDPI, Basel, Switzerland. This article is an open access article distributed under the terms and conditions of the Creative Commons Attribution (CC BY) license (http:/ / creativecommons.org/licenses/by/4.0/). 